\title{
Performance of sweet passion fruit seeds submitted to pre- germination treatments
}

Desempenho de sementes de maracujá doce submetidas a tratamentos pré-germinativos

\author{
N. A. B. Fávaris ${ }^{1}$; J. C. Lopes ${ }^{1 *}$; A. R. de Freitas ${ }^{1}$; P. A. Cabanez¹; R. S. \\ Alexandre ${ }^{2}$ \\ ${ }^{1}$ Departamento de Agronomia, Universidade Federal do Espírito Santo, 29500-000, Alegre-ES, Brazil \\ ${ }^{2}$ Departamento de Ciências Florestais e da Madeira, Universidade Federal do Espírito Santo, 29550-000, Jerônimo \\ Monteiro-ES, Brazil \\ *jcufes@bol.com.br
}

(Recebido em 13 de março de 2020; aceito em 11 de junho de 2020)

\begin{abstract}
Brazil is the world's largest consumer and producer of passion fruit (Passiflora spp.). Its fruit is widely accepted by consumers mainly in terms of natura consumption, juices, and medicines. However, these plants are spread mainly via seminiferous propagation, in which low and uneven seed germination is verified. The objective of this work was to study seed performance and initial growth of Passiflora alata Curtis seedlings as a function of pre-germination treatments. Seeds of $P$. alata extracted from mature fruits harvested were used and manually extracted from the fruits, and the aryl was removed by rubbing in a stainless steel mesh sieve with quicklime, followed by drying in the shade on filter paper for 24 hours. The seeds were submitted to physical scarification and immersed in distilled water for $0 ; 24 ; 48 ; 72 ; 96$; and 120 hours of stirring. The seed scarification method by cracking interferes negatively in the germination and initial growth of $P$. alata seedlings. Intact seeds had a higher percentage of germination as the stirring time of the seeds imbibed in water increased. The cracked seed treatment provided the highest averages when electrical conductivity was evaluated in the stirring time of 120 hours. Intact seeds immersed in distilled water with stirring for 120 hours provide greater germination and initial growth of $P$. alata Curtis seedlings. Keywords: germination, mechanical stirring, Passiflora alata Curtis.
\end{abstract}

O Brasil é o maior consumidor e produtor mundial de maracujás (Passiflora spp.). Seu fruto apresenta grande aceitação pelos consumidores principalmente quanto ao consumo in natura, sucos e medicamentos. Todavia, a propagação das plantas ocorre, principalmente via seminífera, em que é verificada baixa e desuniforme germinação das sementes. Objetivou-se com este trabalho estudar o desempenho de sementes e o crescimento inicial de plântulas de Passiflora alata Curtis em função de tratamentos pré-germinativos. Sementes de $P$. alata extraídas de frutos maduros colhidos foram utilizadas e extraídas manualmente dos frutos, e o arilo foi removido esfregando uma peneira de malha de aço inoxidável com cal rápida, seguido de secagem à sombra em papel de filtro por 24 horas. Foram utilizadas sementes de $P$. alata submetidas à escarificação física e imersas em água destilada por 0; 24; 48; 72; 96 e 120 horas de agitação. As sementes intactas apresentaram uma porcentagem mais alta de germinação, à medida do acréscimo no tempo de agitação das sementes. O tratamento de sementes trincadas proporcionou as maiores médias quando a condutividade elétrica foi avaliada no tempo de agitação de 120 horas. O método de escarificação das sementes por trincagem interfere negativamente na germinação e crescimento inicial das plântulas de $P$. alata. Sementes intactas e imersas em água destilada com agitação por 120 horas proporcionam maior germinação e crescimento inicial das plântulas de $P$. alata Curtis.

Palavras-chave: germinação, agitação mecânica, Passiflora alata Curtis.

\section{INTRODUCTION}

Brazil is the world's leading producer and consumer of passion fruit (Passiflora spp.), with a production of 703 tons, obtained in an area of 41000 hectares [1]. These species are native from tropical America, where Brazil presents excellent conditions for their cultivation, with more than 150 native species, being the yellow passion fruit (Passiflora edulis f. Flavicarpa Degener), purple passion fruit (Passiflora edulis Sims), and sweet passion fruit (Passiflora alata Curtis) the most cultivated worldwide [2]. 
Brazil has been a major producer of yellow passion fruit in the last decades [3], which is cultivated mainly in small and medium-sized properties [4], mainly for use in family farming [5]. In this context, the cultivation of sweet passion fruit is noteworthy because it has great acceptance by the population, largely for its sweet taste and in natura consumption [6], which guarantees high market price.

The seminiferous propagation is the main method for spreading passion fruit species. However, the germination of sweet passion fruit seeds is low and uneven $[7,8,9]$, which may be associated with integument impermeability, physiological immaturity, embryo immaturity, and the presence of inhibitory substances [10]. For the Passifloraceae family, dormancy is an important factor in the study of seeds, mainly because they present embryo, endosperm, integument, and aryl in their constitution, and some of these structures, such as aryl and integument, can influence seed dormancy. In addition to these seed coats, the temperature at which the seed is subjected during germination, as well as the light, balance of phytoregulatory substances, time, storage conditions, and seed genetics influence its germination and/or dormancy [6].

The overcoming of seed dormancy of $P$. alata is favored by scarification techniques, alternating temperatures, and application of plant regulators, which increase the water imbibition by the seed [11]. The scarification technique provides a rupture in the physical impediment of the seed integument by physical, mechanical, or chemical means, favoring germination $[12,13]$. Due to the hindrances of seed germination, several studies have been developed in order to study the germination of Passiflora spp. [5, 14]. However, the Passifloraceae family presents high potential as rootstocks because they are resistant to foliar and soil diseases [15], demonstrating the need for studies regarding the overcoming of seed dormancy. Therefore, the objective of this work was to study the germination and initial growth of $P$. alata seedlings as a function of pre-germination treatments.

\section{MATERIAL AND METHODS}

The experiment was conducted at the Laboratory of Seed Analysis of the Center for Agrarian Sciences and Engineering of the Federal University of Espírito Santo (CCAE-UFES), in AlegreES. Seeds of $P$. alata Curtis extracted from mature fruits harvested in orchards in the municipality

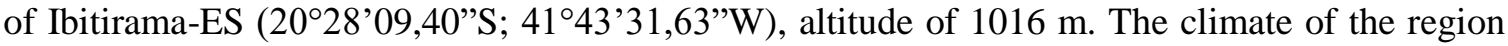
is warm and temperate Cwa, with an average temperature of $19.8^{\circ} \mathrm{C}$ and an annual average precipitation of $1,286 \mathrm{~mm}[16]$.

The seeds were manually extracted from the fruits, and the aryl was removed by rubbing in a stainless steel mesh sieve with quicklime, in a ratio of 1:2 in relation to the pulp volume, followed by drying in the shade on filter paper for 24 hours. The treatments constituted of physical scarification of the seeds: cracked seeds (CS), with the aid of a bench vice; scarified seeds (SS), with sandpaper No. 100, on the opposite side to the embryo; and intact seeds (SI). The seeds were conditioned in Erlenmeyer flasks with $100 \mathrm{~mL}$ of distilled water and separated into six lots of 100 seeds, composing the treatments with stirring for 24, 48, 72, 96, and 120 hours on an automatic magnetic stirrer at $150 \mathrm{rpm}$. Every 24 hours, a lot of seeds was removed from each treatment, and the $\mathrm{pH}$ and electrical conductivity of the water were analyzed.

Prior to sowing, the seeds were submitted to a desinfestation process with $70 \%$ alcohol (oneminute immersion), $2 \%$ sodium hypochlorite (five-minute immersion), and captan ${ }^{\circledR}(5 \% \mathrm{w} / \mathrm{v})$. Sowing was carried out on two sheets of Germitest ${ }^{\circledR}$-type paper, covered by another sheet, which were moistened with distilled water in an amount equivalent to 2.5 times the dry paper mass. Subsequently, the paper rolls were kept in BOD (Biochemical Oxygen Demand) type chambers, under alternating temperatures of $20-30^{\circ} \mathrm{C}$ and absence of light for 45 days [17].

The experiment was set up in a completely randomized design, in a factorial scheme $3 \times 6$ (types of physical scarification $\mathrm{x}$ time of immersion in water under stirring), containing four replicates of 25 seeds per treatment. For the analysis of seed physiological quality, the following determinations were made: $\mathrm{pH}$, with the aid of a Digimed DMPH-2 digital $\mathrm{pH}$ meter; electrical conductivity $\left(\mu \mathrm{S} \mathrm{cm}^{-1} \mathrm{~g}^{-1}\right)$, by means of a MS Tecnopon conductivity meter; seed water content $(\%)$, with the aid of an oven at $105 \pm 3^{\circ} \mathrm{C}$ for 24 hours, with two replicates of 20 seeds weighed on a scale with a precision of $0.0001 \mathrm{~g}$ [17]. We also evaluated the rate of germination $(\mathrm{G})$, with 
daily counting of germinated seeds. Furthermore, after 30 days of sowing, the total of germinated seeds was computed and the results expressed as percentage. The germination velocity index (GVI) was made concomitantly with the germination test, considering the protrusion of the primary root $\geq 2 \mathrm{~mm}$, according to Maguire (1962) [18]. Both shoot (SL) and root length (SR) were determined with normal seedlings obtained in the germination test, after 30 days of sowing, with the aid of a digital caliper $(0.01 \mathrm{~mm})$. The total fresh and dry mass of the seedlings were determined after 30 days of sowing, by means of an analytical balance $(0.0001 \mathrm{~g})$. After obtaining the fresh mass, the seedlings were conditioned in bags of Kraft paper, kept in a convection oven at $72^{\circ} \mathrm{C}$ for 72 hours. Subsequently, the samples were weighed, obtaining the total dry mass and the results were expressed in $\mathrm{mg}_{\text {seedling }}{ }^{-1}$.

The germination percentage data were transformed into arc $\sin \sqrt{ } \mathrm{x} / 100$ and further data into (x $+0.5)^{1 / 2}$, observing the assumptions of the normality test and homogeneity of variance. The ANOVA was carried out and, subsequently, the means were compared by the Tukey test ( $\alpha=$ 0.05). The regression analysis was performed for the quantitative data. Moreover, statistical analyses were performed with the aid of the software R [19].

\section{RESULTS AND DISCUSSION}

The seed water content after harvesting and processing revealed moisture values of $18.63 \%$. In the analysis of electrical conductivity, it was verified that there was an increase in the values associated with the increase of the stirring time in which seeds were exposed (Figure 1a). The cracked and intact seed treatments stood out with the highest values. However, there was no difference in water $\mathrm{pH}$ related to the stirring time for scarified and intact seeds (Figure 1b).
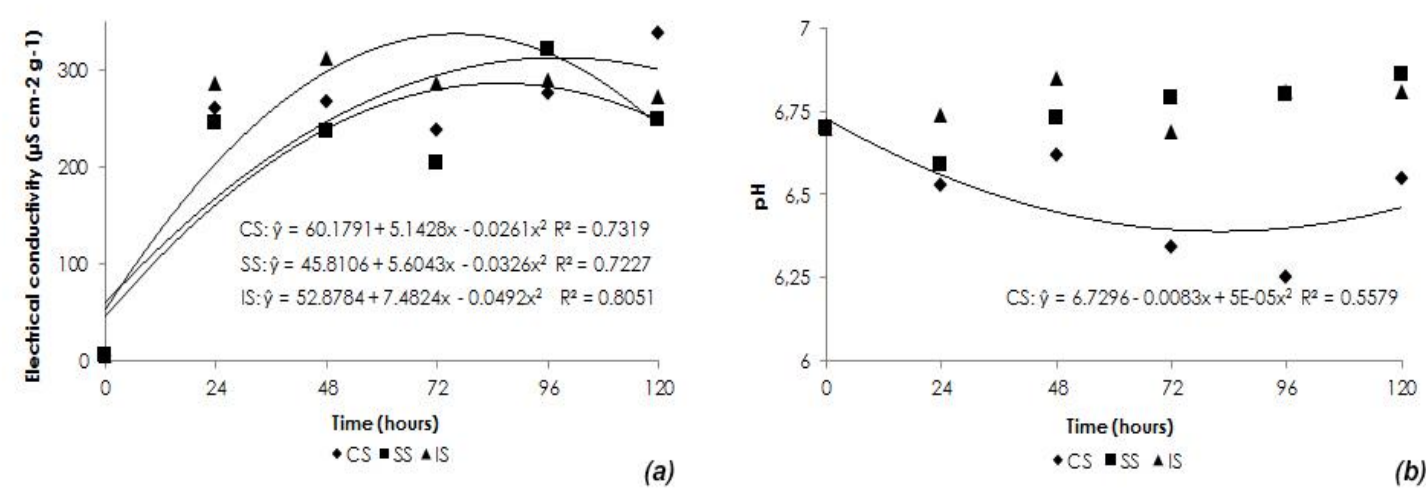

Figure 1: Electrical conductivity $(a)$ and $p H(b)$ as a function of the stirring time treatments in water with cracked seeds (CS), scarified seeds (SS), and intact seeds (IS) of sweet passion fruit (P. alata Curtis).

The process of seed imbibition in water for longer periods under stirring leads to the release of several substances that are present in the seed integument, e.g. inorganic ions, sugars, amino acids, enzymes, nucleotides, and fatty acids [10]. The electrical conductivity is associated with the release of substances through the disorganization of cell membranes, in which high values of electrical conductivity suggest a higher exudation of organic solutes by the membranes and lower vigor of the seeds. On the other hand, low values suggest a higher degree of organization of the membranes and greater vigor of the seeds.

Similar results were found by Dalanhol et al. (2014) [20] when evaluating the electrical conductivity of the water in which seeds of Bowdichia virgilioides Kunth were submitted. These authors verified that the increase in electrical conductivity was correlated with the increase in time of seed imbibition. According to Bewley and Black (1994) [21], the loss of the integrity of the membrane of the tonoplast and of the plasmalema of the cells begins with the physiological maturation of the seeds, impairing the selective permeability. In addition, there is a reduction in osmotic potential leads to slower imbibition, as the water available to seed tissue is less, therefore there is a decrease in damage caused as the disorganization of membranes and leaching of intracellular components. 
Regarding the analysis of $\mathrm{pH}$ (Figure 1b), there were no differences between the treatments, and their influence on seed germination was not verified, corroborating with the results obtained for P. alata Curtis seeds [22]. However, these results diverge from those obtained with Araucaria angustifolia seeds, which were at an advanced stage of deterioration [23].

Intact seeds had a higher percentage of germination as the stirring time of the seeds imbibed in water increased (Figure 2a). In the intact and scarified seeds, there was a linear increase in germination and vigor as a function of the stirring time, analyzed by the germination velocity index (Figure 2b), in relation to the cracked seeds. These results corroborate with those obtained by Wagner Júnior et al. (2007b) [24], who verified that sweet passion fruit seeds imbibed in distilled water presented a higher germination rate and germination speed index.
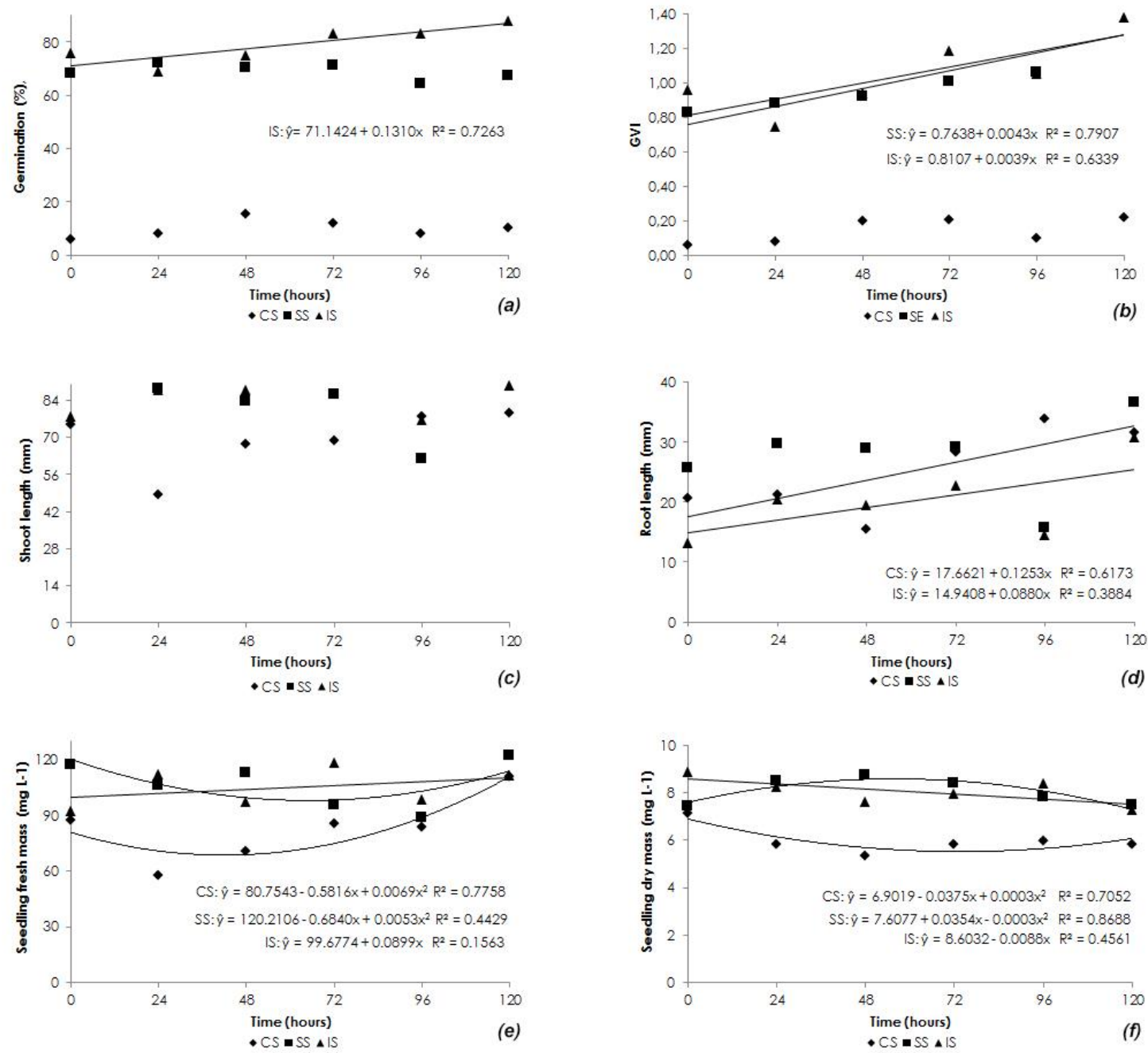

Figure 2: Germination (a), germination velocity index (b), shoot length $(c)$, root length $(d)$, seedling fresh mass $(e)$ and dry mass $(f)$ as a function of the stirring time treatments in water with cracked seeds $(C S)$, scarified seeds (SS), and intact seeds (IS) of sweet passion fruit (P. alata Curtis).

Passifloraceae seeds present imbibition difficulties during the germination process due to the presence of integument hardness, characterized by the presence of lignin, suberin, and other germination-inhibiting substances present in the seed coat [6]. These inhibitory substances may be related to physical factors (impermeability of the integument to water and gases), chemical (presence of inhibitory factors), mechanical (integument resistance to embryo growth), or physiological (physiological mechanisms of inhibition of germination) [25].

The highest values of shoot length were observed at the 120-hour stirring time treatment although it did not differ from the other stirring time treatment (Figure 2c). A similar pattern was observed for root growth (Figure 2d). In seeds of physic nut (Jatropha curcas L.), mechanical 
scarification and water immersion for 12 hours resulted in an increase in seedling length [26], while an increase in root length of $P$. alata seedlings from pre-imbibed seeds was observed [24].

Similarly, the stirring time treatment of 120 hours resulted in an increase in seedling fresh and dry mass (Figures $2 \mathrm{e}$ and $2 \mathrm{f}$ ), contradicting the results obtained with pumpkin seeds treated by different periods of imbibition [27]. For all the analyzed variables, the highest averages were found under the longest stirring time treatment (120 hours) (Table 1), increasing seed germination percentage and vigor of seedlings from intact seeds. These results differ from those found by Lopes et al. (2013) [7], who verified an increase in the emergence of seedlings in scarified seeds of $P$. edulis f. flavicarpa and P. alata

Table 1: Germination $(G)$, germination velocity index (GVI), shoot length $(S L)$, root length $(R L)$, shoot fresh mass (SFM), shoot dry mass (SDM) of seedlings sweet passion fruit (P. alata Curtis). pH and electrical conductivity (EC) as a function of the stirring time treatments in water (independent variable) with cracked seeds (CS), scarified seeds (SS), and intact seeds (IS) of sweet passion fruit (P. alata).

\begin{tabular}{|c|c|c|c|c|c|c|c|c|c|}
\hline $\begin{array}{c}\text { Time } \\
\text { (Hours) }\end{array}$ & Treat. & G $(\%)$ & GVI & SL $(\mathbf{m m})$ & $\begin{array}{c}\mathbf{R L} \\
(\mathbf{m m})\end{array}$ & $\begin{array}{c}\text { SFM } \\
\left(\mathrm{mg} \mathrm{L}^{-1}\right)\end{array}$ & $\begin{array}{c}\text { SDM } \\
\left(\mathrm{mg} \mathrm{L}^{-1}\right)\end{array}$ & pH & 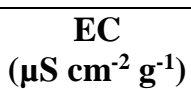 \\
\hline \multirow[t]{3}{*}{0} & ST & $6 \mathrm{~b}$ & $0,06 \mathrm{~b}$ & $74,75^{\mathrm{ns}}$ & $20,63 \mathrm{ab}$ & $87,09 \mathrm{~b}$ & $7,15 \mathrm{~b}$ & $6,70 \mathrm{a}$ & $4,62 \mathrm{a}$ \\
\hline & SE & $68 \mathrm{a}$ & $0,83 \mathrm{a}$ & 90,68 & $25,63 \mathrm{a}$ & 117,17 a & $7,45 \mathrm{~b}$ & $6,70 \mathrm{a}$ & $4,62 \mathrm{a}$ \\
\hline & SI & $76 \mathrm{a}$ & $0,96 \mathrm{a}$ & 78,08 & $13,13 \mathrm{~b}$ & $92,55 \mathrm{~b}$ & $8,91 \mathrm{a}$ & $6,70 \mathrm{a}$ & $4,62 \mathrm{a}$ \\
\hline \multirow[t]{3}{*}{24} & ST & $8 \mathrm{~b}$ & $0,08 \mathrm{~b}$ & $48,25^{\mathrm{ns}}$ & $21,25 \mathrm{ab}$ & $57,58 \mathrm{~b}$ & $5,85 \mathrm{~b}$ & $6,53 \mathrm{a}$ & 260,36 a \\
\hline & SE & $72 \mathrm{a}$ & $0,88 \mathrm{a}$ & 88,50 & $29,73 \mathrm{a}$ & $105,84 \mathrm{a}$ & $8,48 \mathrm{a}$ & $6,59 \mathrm{a}$ & 244,83 a \\
\hline & SI & $69 \mathrm{a}$ & $0,75 \mathrm{a}$ & 87,85 & $20,50 \mathrm{~b}$ & $112,01 \mathrm{a}$ & $8,27 \mathrm{a}$ & $6,74 \mathrm{a}$ & 286,38 a \\
\hline \multirow[t]{3}{*}{48} & ST & $15 \mathrm{~b}$ & $0,20 \mathrm{~b}$ & $67,35^{\mathrm{ns}}$ & $15,50 \mathrm{~b}$ & $70,64 \mathrm{~b}$ & $5,36 \mathrm{c}$ & $6,62 \mathrm{~b}$ & $267,31 \mathrm{~b}$ \\
\hline & SE & $70 \mathrm{a}$ & $0,92 \mathrm{a}$ & 83,73 & $28,89 \mathrm{a}$ & 112,48 a & $8,73 \mathrm{a}$ & $6,73 a b$ & $236,14 \mathrm{~b}$ \\
\hline & SI & $75 \mathrm{a}$ & $0,95 \mathrm{a}$ & 87,75 & $19,55 \mathrm{~b}$ & $97,46 \mathrm{a}$ & $7,61 \mathrm{~b}$ & $6,85 \mathrm{a}$ & $311,68 \mathrm{a}$ \\
\hline \multirow[t]{3}{*}{72} & ST & $12 \mathrm{c}$ & $0,21 \mathrm{c}$ & $68,88^{\mathrm{ns}}$ & $28,25 \mathrm{a}$ & $85,31 \mathrm{~b}$ & $5,84 \mathrm{~b}$ & $6,34 \mathrm{~b}$ & $238,20 \mathrm{~b}$ \\
\hline & SE & $71 \mathrm{~b}$ & $1,01 \mathrm{~b}$ & 86,00 & $29,08 \mathrm{a}$ & $95,63 \mathrm{~b}$ & $8,39 \mathrm{a}$ & $6,79 \mathrm{a}$ & $202,77 \mathrm{~b}$ \\
\hline & SI & $83 \mathrm{a}$ & $1,19 \mathrm{a}$ & 98,78 & $22,73 \mathrm{a}$ & $118,30 \mathrm{a}$ & $7,97 \mathrm{a}$ & $6,69 \mathrm{a}$ & 287,18 a \\
\hline \multirow[t]{3}{*}{96} & ST & $8 \mathrm{c}$ & $0,10 \mathrm{~b}$ & $77,75^{\mathrm{ns}}$ & $33,97 \mathrm{a}$ & 83,60 a & $5,98 \mathrm{~b}$ & $6,25 \mathrm{~b}$ & $275,55 \mathrm{~b}$ \\
\hline & SE & $64 \mathrm{~b}$ & $1,06 \mathrm{a}$ & 61,93 & $15,70 \mathrm{~b}$ & $88,42 \mathrm{a}$ & $7,84 \mathrm{a}$ & $6,80 \mathrm{a}$ & $321,20 \mathrm{a}$ \\
\hline & SI & 83 a & $1,05 \mathrm{a}$ & 76,49 & $14,60 \mathrm{~b}$ & 98,58 a & $8,41 \mathrm{a}$ & $6,81 \mathrm{a}$ & $290,73 \mathrm{ab}$ \\
\hline \multirow[t]{4}{*}{120} & ST & $10 \mathrm{c}$ & $0,22 b$ & $79,08^{\mathrm{ns}}$ & $31,50 \mathrm{a}$ & $110,65 \mathrm{a}$ & $5,82 \mathrm{~b}$ & $6,55 \mathrm{~b}$ & 338,32 a \\
\hline & SE & $67 \mathrm{~b}$ & $1,44 \mathrm{a}$ & 94,88 & $36,55 \mathrm{a}$ & $122,10 \mathrm{a}$ & $7,47 \mathrm{a}$ & $6,86 \mathrm{a}$ & $249,22 \mathrm{~b}$ \\
\hline & SI & $88 \mathrm{a}$ & $1,39 \mathrm{a}$ & 89,63 & $30,83 \mathrm{a}$ & $111,55 \mathrm{a}$ & $7,28 \mathrm{a}$ & $6,81 \mathrm{a}$ & $272,60 \mathrm{~b}$ \\
\hline & $\mathrm{CV}(\%)$ & 12,64 & 12,56 & 11,40 & 21,86 & 9,10 & 7,71 & 1,91 & 10,48 \\
\hline
\end{tabular}

Means followed by the same letter do not differ by the Tukey test, at a 5\% probability level. ns: not significant.

There were no significant differences in shoot length in all treatments studied (Table 1). Wagner Júnior et al. (2007b) [24] concluded that seeds of $P$. alata Curtis pre-imbibed in water showed an increase in total length and root length of seedlings.

Considering the root length, seedling fresh and dry mass, and the $\mathrm{pH}$ of the imbibition water, it was found that the stirring time of 120 hours provided higher averages for scarified seeds when compared to the cracked and intact ones (Table 1), in contrast with the results observed by Wagner Júnior et al. (2007a) [28].

The cracked seed treatment provided the highest averages when electrical conductivity was evaluated in the stirring time of 120 hours, differing statistically from the others (Table 1), suggesting that in this treatment, the seeds had a higher release of exudates in the water. Electrical conductivity is related to seed quality, in which smaller values indicate a lower release of exudates and, consequently, greater vigor since in these situations there is less disintegration of cell membranes $[29,30]$. This happens mainly because during seed hydration, there is a release of 
solutes such as sugars, organic acids, amino acids, and various ions, which stimulate the appearance and development of pathogens, subsequently causing and accelerating seed deterioration [10].

\section{CONCLUSIONS}

Intact seeds of $P$. alata show a higher percentage of germination. The stirring time treatment of 120 hours provides greater germination and growth of the seedlings of $P$. alata.

Cracked seeds of $P$. alata showed lower germination and vigor in relation to the other scarification methods.

Cracking of $P$. alata seeds causes a greater release of exudates and increase of electrical conductivity.

\section{ACKNOWLEDGMENTS}

FAPES and CNPq for granting scholarships to the first, and second and fourth authors, respectively.

\section{REFERENCES}

1. IBGE. Instituto Brasileiro de Geografia e Estatística. 2019.http://www.ibge.gov.br<Acesso em 14 janeiro de 2019>

2. Faleiro, FG, Junqueira, NTV, Braga, MF, Oliveira, EJ, Peixoto, JR, Costa, AM. 2011. Germoplasma e melhoramento genético do maracujazeiro: histórico e perspectivas. Embrapa Cerrados, Planaltina, Brasil. 36 p. (Documentos/Embrapa Cerrados No 307). Ferrari, T. B., Ferreira, G.,

3. Meletti, LMM. Avanços na cultura do maracujá no Brasil. Rev Brasileira Fruticultura 2011,33:83-91.

4. Furlaneto, FPB, Esperancini, MST, Martins, AN, Okamoto, F, Vidal, AA, Bueno, OC. Análise energética do novo sistema de produção de maracujá amarelo na região de Marília-SP. Ciênc Rural 2014,44:235-240.

5. Santos, CHB, Neto, AJC, Junghans, TG, Jesus, ON, Girardi, EA. Estádio de maturação de frutos e influência de ácido giberélico na emergência e crescimento de Passiflora spp. Rev Ciênc Agron 2016,47:481-490.

6. Alexandre, RS, Otoni, WC, Dias, JM, Bruckner, CH, Lopes, JC. Propagação vegetativa ex vitro do maracujazeiro: estaquia e enxertia. In: Alexandre, R. S., Bruckner, C. H., Lopes, J. C. Propagação do maracujazeiro. EDUFES, Vitória, Brasil, 2009. p 210.

7. Lopes, J.C., Tiradentes, A.T., Alexandre, R.S. 2013. Emergência e crescimento inicial de plântulas de maracujazeiro para obtenção de porta enxertos. Magistra, 2013,25:55-62.

8. Freitas, AR, Lopes, JC, Alexandre, RS, Venancio, LP, Zanotti, RF. Emergência e crescimento de mudas de maracujá doce em função de lodo de esgoto e luz. Comunic Scient 2015,2:234-240.

9. Freitas, AR, Lopes, JC, Mengarda, LHG, Zanotti, RF, Venancio, LP. Allelopathic effect of Passiflora alata Curtis extracts on seed germination. Comunic Scient 2016,7:129-132.

10. Bewley, JD, Bradford, KJ, Hilhorst, HWM, Nonogaki, H. Seeds: physiology of development, germination and dormancy. Springer, New York, USA. 2013. 392 p, doi: 10.1007 / 978-1-4614-4693-4

11. Oliveira Júnior, MX, São José, AR, Rebouças, TNH., Morais, OM, Dourado, FWN. Superação de dormência de maracujá-do-mato (Passiflora cincinnata Mast.). Rev Bras Fruticultura 2010,32:584-590, doi: 10.1590/S0100-29452010005000045

12. Hermansen, LA, Duyea, ML, White, TL. Variability in seed coat dormancy in Dimorphandra mollis. Seed Science and Technology 2000,28:567-580.

13. Freitas, VLO, Alves, THS, Lopes, RMF, Lemos Filho, JPL. Biometria de frutos e sementes e germinação de sementes de Dimorphandra mollis Benth e Dimorphandra wilsonni Rizz. (Fabaceae Ceasalpinoideae). Scientia Forest 2009,37:27-35.

14.Zucareli, V., Ferreira, G., Amaro, ACE, Fazio, JL. GA4+7 + N-(fenilmetil)-aminopurina na germinação de sementes e emergência de plântulas de Passiflora cincinnata Mast. Rev Bras Fruticultura 2009,31:216-223, doi: S0100-29452009000100030

15. Lenza, JB, Valente, JP, Roncatto, G, Abreu, JA. Desenvolvimento de mudas de maracujazeiro propagadas por enxertia. Rev Bras Fruticultura 2009,31:135-140.

16. INMET. Instituto Nacional de Meteorologia. 2019. http://www.inmet.gov.br/portal/<Acesso em 02 de janeiro de 2019> 
17. Brasil. Regras para análise de sementes. MAPA-ACS, Brasília, Brasil. 2009. 395p.

18. Maguire, JD. Speeds of germination-aid selection and evaluation for seedling emergence and vigor. Crop Science 1962,2:176-177.

19. R Core Team R A language and environment for statistical computing. 2019. R Foundation for Statistical Computing, Vienna, Austria.

20. Dalanhol, SJ, Rezende, EH, Abreu, DCA, Nogueira, AC. Teste de condutividade elétrica em sementes de Bowdichia virgilioides Kunth. Florest Amb 2014, 21:69-77.

21. Bewley, JD, Black, M. Seeds: physiology of development and germination. New York: Plenum Press, 1994. 445p

22. Wagner Júnior, A, Santos, CEM, Silva, JOC, Alexandre, RS, Negreiros, JRS, Pimentel, LD, Álvares, VS, Bruckner, CH. Influência do ph da água de embebição das sementes e do substrato na germinação e desenvolvimento inicial do maracujazeiro doce. Rev Bras Agroc 2006,12:231-235.

23. Araldi, CG, Coelho, CMM. pH do exsudato na avaliação da viabilidade de sementes de Araucaria angustifólia. Florest Ambiente 2015,22:426-433.

24. Wagner Júnior, A, Santos, CEM., Alexandre, RS, Silva, JOC, Negreiros, JRS, Pimentel, LD, Álvares, VS, Bruckner, CH. Efeito da pré-embebição das sementes e do substrato na germinação e no desenvolvimento inicial do maracujazeiro-doce. Rev Cer 2007b,54:1-6.

25. Delanoy, M., Van Damme, P, Scheldeman, X, Beltran, J. Germination of Passiflora mollissima (Kunth) L.H.Bailey, Passiflora tricuspis Mast. and Passiflora nov sp. seeds. Sci Hortic 2006,1:198-203.

26. Moreira, EF, Boliani, AC, Corrêa, LS, Pagliarini, MK, Santos, DMA., Junior, EF, Pereira, GA. Tratamentos pré-germinativos e substratos na emergência de sementes e qualidade de mudas de pinhão manso (Jatropha curcas L.). Semina: Ciênc Agrár 2019,36:657-668, doi: 10.5433/16790359.2015v36n2p657

27. Sales, MAL, Moreira, FJC, Ribeiro, AA, Monteiro, RNF, Sales, FAL. Potencial das sementes de abóbora submetidas a diferentes períodos de embebição. Brazilian Journal of Biosystems Engineering 2015, 9:289-297.

28. Wagner Júnior, A, Negreiros, JRS, Alexandre, RS, Pimentel, LD, Bruckner, CH. Efeito do pH da água de embebição e do trincamento das sementes de maracujazeiro amarelo na germinação e desenvolvimento inicial. Ciênc Agrotec 2007a,31:1014-1019.

29. Vieira, RD, Krzyzanowski, FC. Teste de condutividade elétrica. In: Krzyzanowski, F. C., Vieira, R. D., França Neto, J. B. (Ed.). Vigor de sementes: conceitos e testes. ABRATES, 1999. Londrina, Brasil. p. $1-26$.

30. Association of Official Seed Analysts. Seed vigour testing handbook. East Lansing: AOSA, 2009. 334 p. 